TP Periodica Polytechnica

Transportation Engineering

47(4), pp. 342-347, 2019

https://doi.org/10.3311/PPtr.12111

Creative Commons Attribution (i)

RESEARCH ARTICLE

\section{The Corrosion Properties of S355J2 Steel Welded Joint in Chlorides Environment}

\author{
Kamil Borko $^{1 *}$, Branislav Hadzima ${ }^{1,2}$, Filip Pastorek ${ }^{2}$
}

Received 25 July 2017; accepted 15 January 2018

\begin{abstract}
Nowadays are steels the most used structural material for creation of constructions in different types of industry for lot of applications but suffer from unsatisfactory corrosion resistance in the presence of aggressive chlorides. Steel S355J2 represents common type steel for constructions. Very important property of S355J2 steel is weldability. S355J2 steel was welded by submerged arc welding (SAW) method. Corrosion resistance of welded joint was evaluated by electrochemical methods - linear polarization (LP) and electrochemical impedance spectroscopy (EIS). Results from electrochemical tests are general electrochemical characteristics $-E_{C o r}, i_{C o r}$, $v_{\text {Corr }}$ and $R_{P}$ Environments for testing were solutions with different concentration of chlorides $(0.01 \mathrm{M}, 0.1 \mathrm{M}$ and $1 \mathrm{M} \mathrm{NaCl}$ solution). Difference of corrosion resistance between base material and weld metal is app. $14.5 \%$. This difference is preserved in all concentrations of tested environments. The highest corrosion resistance was reached by base material in $0.01 \mathrm{M} \mathrm{NaCl}$ and the lowest corrosion resistance was reached by weld metal in $1 \mathrm{M} \mathrm{NaCl}$.
\end{abstract}

\section{Keywords}

steel, corrosion, S355, welding, welded joint

\footnotetext{
${ }^{1}$ Department of Materials Engineering,

Faculty of Mechanical Engineering,

University of Žilina,

Univerzitná 8215/1, 01026 Žilina, Slovakia

${ }^{2}$ Research Centre,

University of Žilina,

Univerzitná 8215/1, 01026 Žilina, Slovakia

*Corresponding author, e-mail: kamil.borko@fstroj.uniza.sk
}

\section{Introduction}

High-strength low-alloy steel (HSLA) is a type of alloy steel that provides better mechanical properties or greater resistance to corrosion than carbon steel. HSLA steels are different from other steels in a specific chemical composition, specific mechanical properties and microstructure (Garcia, 2017).

As an alloying elements HSLA steels includes up to $2 \%$ of manganese and small quantities of copper, nickel, niobium, nitrogen, vanadium, chromium, molybdenum, titanium, calcium, rare earth elements, or zirconium. These elements are intended to change the microstructure of carbon steels, which is usually a ferrite-pearlite matrix, to produce a very fine dispersion of alloyed carbides in an almost pure ferritic matrix. This eliminates the toughness-reducing effect of a pearlitic volume fraction, which maintains and increases the material's strength by refining the grain size, which in the case of ferrite increases yield strength by $50 \%$ for every halving of the mean grain diameter. Yield strength can be between 250 - 590 $\mathrm{MPa}$. Introduction of HSLA steels is a breakthrough in the steel industry. Their worldwide use in the automotive, oil, gas, and other industries represents both a challenge and an opportunity to improve the performance of these steels (Garcia, 2017; Alipooramirabad et al., 2017).

S355J2 steel is ranked to HSLA steels. It is used for many applications in practice and in various industries (welded constructions, rolled products, pressure vessels, pipes ...). This material (S355 steel) can be welded by all conventional methods of welding (MIG, MAG, TIG, GMAW, SAW, friction welding ...) (Vural, 2014).

One of the most characteristic phenomenon of arc welding is molten metal transferring across the arc from the wire electrode to the molten pool. This behaviour directly affects the appearance and quality of welds. In gas metal arc welding (GMAW), the arc shape and metal transfer can be observed directly. However, in submerged arc welding (SAW), because the electric arc is shielded by a blanket of granular fusible flux, the arc and molten metal at the tip of electrode cannot be observed directly, and this can be affected quality, appearance and corrosion resistance of welds (Li (K.) et al., 2017). 
Submerged arc welding (SAW) is an arc welding process and the arc is shielded by a layer of flux which protects the molten weld metal from atmospheric contamination. The base metal (BM), the heat affected zone (HAZ) and the weld metal (WM) are parts of the welded joint and define the properties of the welded joints and welded constructions. While the WM is produced by a chemical and physical reaction of the weld electrode, the base metal and the flux and the alloying elements coming from them, the HAZ microstructure and mechanical properties are depend on the temperature degree being applied and the thermal cycle (Sirin et al., 2016; Pu et al., 2017).

Submerged arc welding is a different way of arc welding, which is different from the manual arc welding: welding wire is pure - without bluntly, weld arc and weld bath are protected by flux, movement of welding wire is mechanized, arc initiation and filling the craters are automated. Flux has the following features: protect of weld bath against air - oxidation, stabilization of arc, refinement of weld bath, weld metal alloying, welding of large thicknesses, slows the cooling of the weld, prevents spattering of weld. Positive properties are: higher productivity of welding and welding of thick materials (Increasing the current intensity it is accompanied by increasing the depth of boiling over, allowing weld metal of high thickness). Welded joints of steel exhibit good mechanical properties and excellent welding ability, however, the corrosion problems caused by chlorides have been paid more and more attention on the pressure vessels (pipelines), large crude oil storage tank (LCOST) by now (Vural, 2014; Weman, 2003; Ren et al., 2009; Forouzan et al., 2012; Ding et al., 2014).

HSLA steels are used in lot of industries sectors. For example the external pipeline corrosion at this region depends on the environment. When a pipeline coating disbonds, for example, the external surface gets in contact with hydrated soil, ground water or sea water. These environments in many of the pipeline projects are of considerable variability, as they contain different concentrations of bicarbonate, carbonate, chloride, and sulfate in mildly alkaline mediums that could be totally de-oxygenated, or contain oxygen and traces of $\mathrm{CO}_{2}$ at different temperatures. These "negative (aggressive) components" of environment can attack surface of materials and can be a katalizator of corrosive attack (Liu et al., 2017; Kim et al., 2008; Li (J.) et al., 2017).

\section{Experimental}

Test specimens were cut from the longitudinally welded S355J2 steel containing WM, HAZ and BM. The chemical compositions of the S355J2 steel and filler metal are shown in Table 1.

Fillet welds were made on plates of $250 \mathrm{~mm} \times 500 \mathrm{~mm}$ $\times 30 \mathrm{~mm}$ using submerged arc welding - SAW. The welded joint is shown in Fig. 1.

Microstructure of S355J2 was observed by confocal microscope - ZEISS AXIO Imager A1m. Samples of experimental material for metallographic analysis were prepared by conventional methods and were etched by $1 \%$ Nital. General mechanical properties are in Table 2 .

Table 1 Chemical composition of S355J2 steel and SAW wire

\begin{tabular}{lccccc}
\hline \multicolumn{5}{c}{ Element (wt. \%) } \\
\hline S3552 & $\mathrm{C}$ & $\mathrm{Mn}$ & $\mathrm{Si}$ & $\mathrm{P}$ & $\mathrm{S}$ \\
& 0.150 & 1.460 & 0.340 & 0.022 & 0.009 \\
& $\mathrm{Ni}$ & $\mathrm{Cr}$ & $\mathrm{Mo}$ & $\mathrm{Pb}$ & $\mathrm{Fe}$ \\
& 0.030 & 0.050 & 0.006 & 0.010 & bal. \\
& $\mathrm{C}$ & $\mathrm{Mn}$ & $\mathrm{Si}$ & $\mathrm{P}$ & $\mathrm{S}$ \\
& 0.100 & 1.010 & 0.080 & 0.013 & 0.012 \\
& $\mathrm{Ni}$ & $\mathrm{Cr}$ & $\mathrm{Mo}$ & $\mathrm{Pb}$ & $\mathrm{Fe}$ \\
& 0.030 & 0.050 & 0.010 & 0.012 & bal. \\
\hline
\end{tabular}

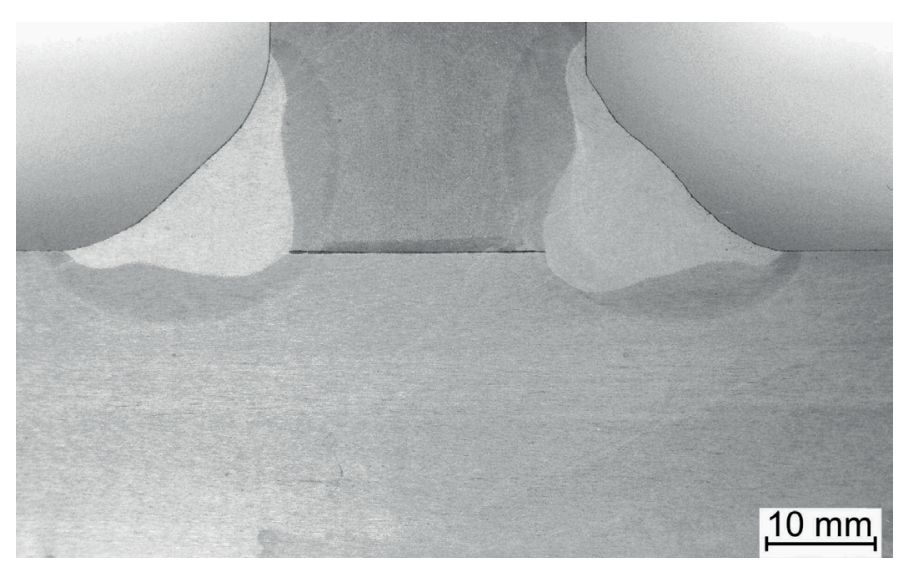

Fig. 1 Welded joint of S355J2 steel

Table 2 General mechanical properties of S355J2 steel

\begin{tabular}{cc}
\hline $\mathrm{R}_{\mathrm{e}} \min .(\mathrm{MPa})$ & $\mathrm{A}_{5}[\%] ; \geq 3 \leq 40(\mathrm{~mm})$ \\
\hline 355 & 22 \\
$\mathrm{R}_{\mathrm{m}}(\mathrm{MPa})$ & Absorbed energy $[\mathrm{J}] ;-20{ }^{\circ} \mathrm{C}$ \\
$450-630$ & 27 \\
\hline
\end{tabular}

* mechanical properties in Table 2 are guaranteed only in the rolling direction

Samples of experimental material were ground by $\mathrm{SiC}$ paper with a grain size of p500 for the surface homogenization. The general potentiodynamic electrochemical characteristics (corrosion potential - $\mathrm{E}_{\text {Corr }}$, corrosion current density - $\mathrm{i}_{\text {Corr }}$, corrosion rate $-\mathrm{v}_{\text {Corr }}$ and polarization resistance $-\mathrm{R}_{\mathrm{p}}$ ) were tested in $0.01 \mathrm{M} \mathrm{NaCl} ; 0.1 \mathrm{M} \mathrm{NaCl}$ and $1 \mathrm{M} \mathrm{NaCl}$ solutions at $20^{\circ} \mathrm{C}$ $\pm 2{ }^{\circ} \mathrm{C}$. Electrochemical measurements were realized on device SP300 from BioLogic SAS France in corrosion cell. Saturated calomel electrode (SCE) was used as a reference electrode, platinum electrode as an auxiliary electrode and a sample as a working electrode. Stabilization of the samples in solutions was 5 minutes. Potentiodynamic polarization curves were measured in the range of potential from $-250 \mathrm{mV}$ to $+300 \mathrm{mV}$ vs. open circuit potential with a constant potential change $1 \mathrm{mV} \cdot \mathrm{s}^{-1}$. Measured potentiodynamic curves were analyzed using Tafel fit by EC-Lab software. EIS measurements were running under potential control with scanning frequency range $100 \mathrm{kHz}$ $10 \mathrm{mHz}$. The perturbation amplitude was $10 \mathrm{mV}$. 


\section{Results}

Microstructure of S355J2 steel is formed by ferrite-pearlite matrix (Fig. 2) with low pearlite content and an average size of grains is approx. $10 \mu \mathrm{m}$. Microstructure of weld material is formed by acicular ferrite (needled ferrite) (Fig. 3) and pearlite.

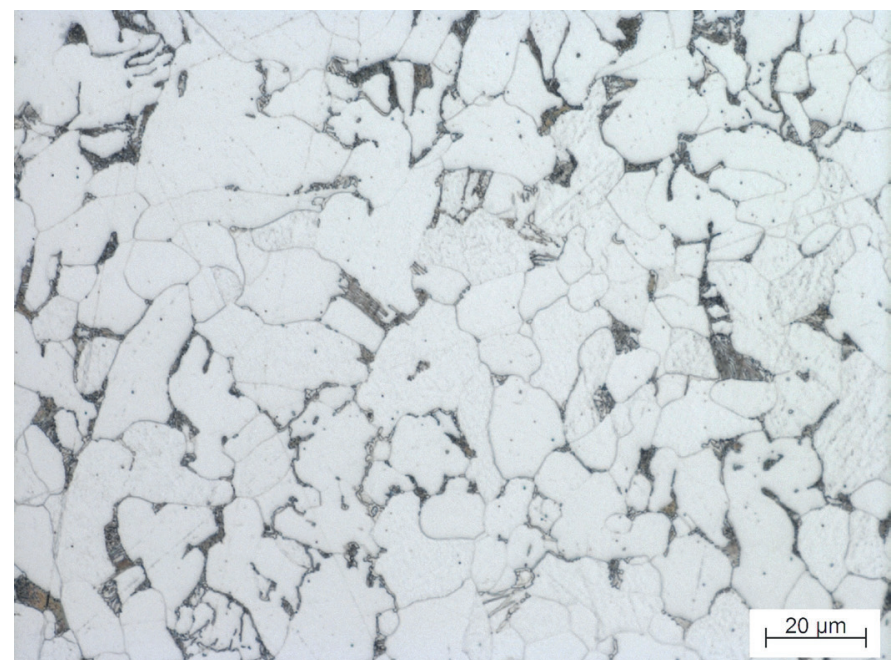

Fig. 2 Microstructure of S355J2 steel (base material)

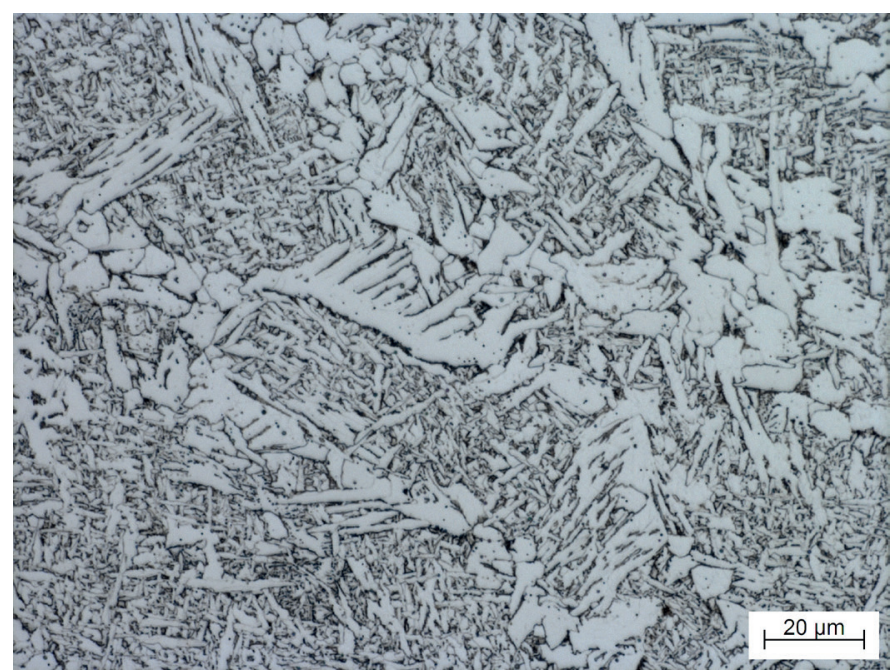

Fig. 3 Microstructure of weld metal

Microstructure of base material and microstructure of weld material was evaluated with use of light metallographic microscope: ZEISS Axio Imager-A1m. Steel was etched by $1 \%$ Nital.

Electrochemical characteristics S355J2 steel were measured by potenciodynamic tests:

- $\mathrm{E}_{\text {Corr }}(\mathrm{mV}$ vs. SCE) - corrosion potential, thermodynamic characteristic of surface of material;

- $\mathrm{i}_{\text {Corr }}\left(\mathrm{mA} . \mathrm{cm}^{-2}\right)$ - corrosion current density, kinetic characteristic of surface of material, which related to the rate of corrosion - $\mathrm{v}_{\text {Corr }}\left(\mathrm{mm} \cdot \mathrm{y}^{-1}\right)$

and electrochemical impedance spectroscopy:

- $\mathrm{R}_{\mathrm{p}}\left(\Omega . \mathrm{cm}^{-2}\right)$ polarization resistance, expresses how resistant surface are against corrosion.
Potentiodynamic curves of base material are presented in Fig. 4 and electrochemical characteristics obtained from Tafel analysis of measured potentiodynamic curves in $0.01 \mathrm{M} \mathrm{NaCl}$; $0.1 \mathrm{M} \mathrm{NaCl}$ and $1 \mathrm{M} \mathrm{NaCl}$ are listed in Table 3. Potentiodynamic curves of weld metal are shown in Fig. 5 and electrochemical characteristics obtained from Tafel analysis of measured potentiodynamic curves in $0.01 \mathrm{M} \mathrm{NaCl}, 0.1 \mathrm{M} \mathrm{NaCl}$ and $1 \mathrm{M}$ $\mathrm{NaCl}$ are listed in Table 4.

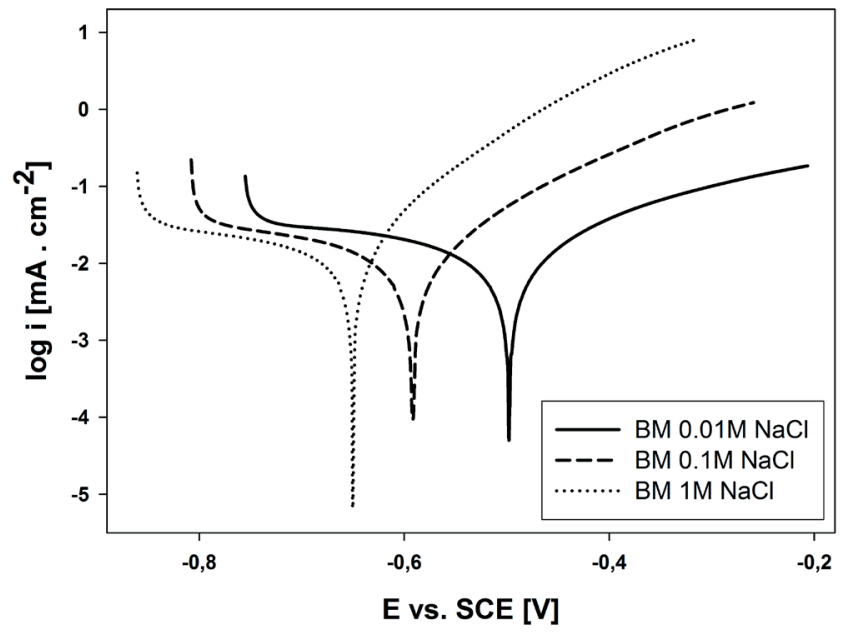

Fig. 4 Potentiodynamic curves of base material (BM)

Table 3 Electrochemical characteristics from linear polarizaton of base material of S355J2 steel

\begin{tabular}{lccc}
\hline \multicolumn{1}{c}{$\begin{array}{c}\text { Electrochemical } \\
\text { characteristic }\end{array}$} & $0.01 \mathrm{M}$ & $0.1 \mathrm{M}$ & $1 \mathrm{M}$ \\
\hline $\mathrm{E}_{\text {Corr }}(\mathrm{mV}$ vs. SCE $)$ & $-498 \pm 15$ & $-591 \pm 10$ & $-650 \pm 11$ \\
$\mathrm{i}_{\text {Corr }}\left(\mu \mathrm{A} \cdot \mathrm{cm}^{-2}\right)$ & $6.5 \pm 1$ & $8.8 \pm 1.2$ & $10.8 \pm 1.1$ \\
$\mathrm{v}_{\text {Corr }}\left(\mu \mathrm{m} \cdot \mathrm{y}^{-1}\right)$ & $151 \pm 18$ & $158 \pm 16$ & $235 \pm 20$ \\
\hline
\end{tabular}

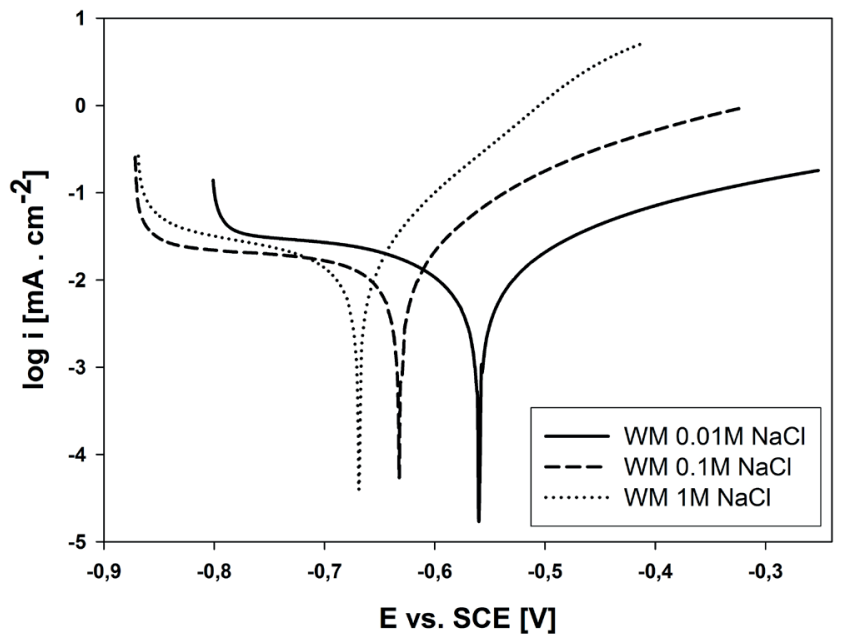

Fig. 5 Potentiodynamic curves of weld metal (WM) 
Table 4 Electrochemical characteristics from linear polarization of weld metal of S355J2 steel

\begin{tabular}{lccc}
\hline $\begin{array}{c}\text { Electrochemical } \\
\text { characteristic }\end{array}$ & $0.01 \mathrm{M}$ & $0.1 \mathrm{M}$ & $1 \mathrm{M}$ \\
\hline $\mathrm{E}_{\text {Corr }}(\mathrm{mV}$ vs. SCE $)$ & $-560 \pm 18$ & $-632 \pm 13$ & $-668 \pm 10$ \\
$\mathrm{i}_{\text {Corr }}\left(\mu \mathrm{A} . \mathrm{cm}^{-2}\right)$ & $7.7 \pm 1.2$ & $10.3 \pm 1.3$ & $12.5 \pm 1.2$ \\
$\mathrm{v}_{\text {Corr }}\left(\mu \mathrm{m} . \mathrm{y}^{-1}\right)$ & $179 \pm 21$ & $251 \pm 27$ & $291 \pm 29$ \\
\hline
\end{tabular}

As seen from obtained results the $\mathrm{E}_{\mathrm{Corr}}$ values are more negative and the $i_{\text {Corr }}$ values increase with an increase of chloride concentration. Difference in corrosion resistance (considering kinetic parameters $\mathrm{i}_{\text {Corr }}$ and $\mathrm{v}_{\text {Corr }}$ ) of the base material and the weld metal is $14.5 \pm 1 \%$ depending on chloride concentration. Generally, increasing of chloride concentration has no significant effect on the value of percentage difference in kinetic corrosion parameters between the base material and the weld metal meaning that both surfaces has very similar sensitivity to chloride concentration change. Base material is also more stable in all tested chloride concentrations than weld metal, showing that it is thermodynamically nobler.

The findings from potentiodynamic polarization tests were supported by non-destructive electrochemical impedance spectroscopy (EIS) measurements.

Fig. 7 and 8 show the Nyquist diagrams of S355J2 steel samples: Fig. 7 - base material (BM) and Fig. 8 - weld metal (WM). Nyquist plots are frequently selected tool for EIS interpretation, allowing precise determination of equivalent circuit components (Hadzima et al., 2014; Wei et al. 2014; Han et al. 2013; Pastorek et al., 2016).

Fig. 6 shows the equivalent circuit best describing the electrochemical processes at the sample-electrolyte interface.

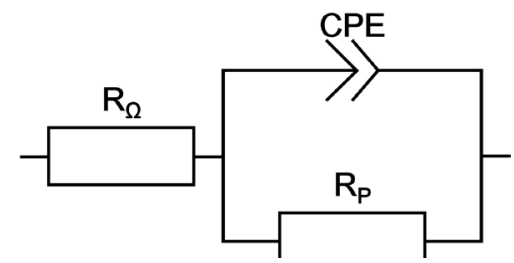

Fig. 6 Equivalent circuit for Nyquist plots analyses

Polarization resistance $R_{P}$ is the most important electrochemical characteristic. The value of $R_{p}$ expresses how resistant the surface (or surface layer) are against corrosion. Component CPE represents a constant phase element. Its function in the expression of EIS data is defined elsewhere (Mhaede et al., 2014; Frankel, 2008). Value of $\mathrm{R}_{\Omega}$ describes environmental resistance. The values of equivalent circuit elements were obtained from the analysis of a selected equivalent circuit using a software EC-Lab (Bio-Logic Science Instruments SAS France, version 11.01). These values are listed in Table 5 and 6. Results from EIS measurements correspond with results from linear polarization. The biggest difference in EIS results is seen

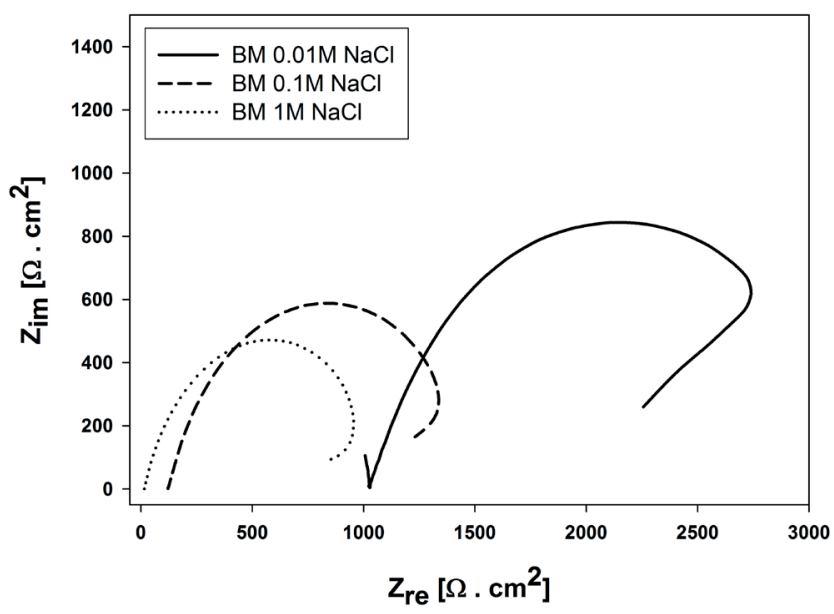

Fig. 7 EIS measurements of base material (BM)

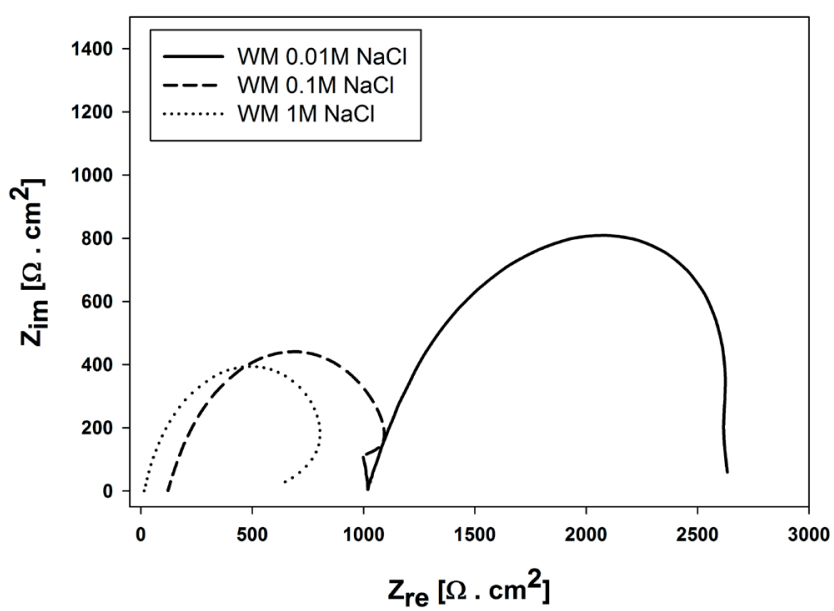

Fig. 8 EIS measurements of weld metal (WM)

in conductivity of environment. Environment with the lowest concentration of chlorides has the lowest conductivity and the highest resistance. With increasing environmental concentration of chlorides in solution its conductivity $(\mathrm{G}, \mathrm{CPE})$ increased and environmental resistance $\left(\mathrm{R}_{\Omega}\right)$ decreased. Different concentration of chlorides $(0.01 \mathrm{M}, 0.1 \mathrm{M}$ and $1 \mathrm{M} \mathrm{NaCl})$ in environment was related the change of polarization resistance $\left(R_{P}\right)$.

Table 5 Electrochemical characteristics from EIS measurements of base material of S355J2 steel

\begin{tabular}{lccc}
\hline $\begin{array}{c}\text { Electrochemical } \\
\text { characteristic }\end{array}$ & $0.01 \mathrm{M}$ & $0.1 \mathrm{M}$ & $1 \mathrm{M}$ \\
\hline $\mathrm{R}_{\Omega}\left(\Omega \cdot \mathrm{cm}^{-2}\right)$ & $1027 \pm 2$ & $123 \pm 2$ & $15.5 \pm 0.5$ \\
$\mathrm{R}_{\mathrm{P}}\left(\Omega \cdot \mathrm{cm}^{-2}\right)$ & $1928 \pm 51$ & $1348 \pm 40$ & $1044 \pm 20$ \\
$\mathrm{CPE}\left(10^{-6} \cdot \mathrm{F} \cdot \mathrm{s}^{\mathrm{n}-1}\right)$ & $168 \pm 14$ & $247 \pm 18$ & $394 \pm 19$ \\
$\mathrm{n}$ & $0.83 \pm 0.5$ & $0.84 \pm 0.6$ & $0.84 \pm 0.5$ \\
\hline
\end{tabular}

It is clear from the results of EIS analysis (Table 5 and Table 6), that the increasing aggresivity (increasing 
concentration of chlorides) of environment causes lower corrosion resistance, this means decreasing value of polarization resistance $\left(\mathrm{R}_{\mathrm{P}}\right)$ for base material and weld metal too.

Table 6 Electrochemical characteristics from EIS measurements of weld metal of S355J2 steel

\begin{tabular}{lccc}
\hline $\begin{array}{c}\text { Electrochemical } \\
\text { characteristic }\end{array}$ & $0.01 \mathrm{M}$ & $0.1 \mathrm{M}$ & $1 \mathrm{M}$ \\
\hline $\mathrm{R}_{\Omega}\left(\Omega \cdot \mathrm{cm}^{-2}\right)$ & $1025 \pm 1.5$ & $122 \pm 1$ & $15.2 \pm 0.5$ \\
$\mathrm{R}_{\mathrm{P}}\left(\Omega \cdot \mathrm{cm}^{-2}\right)$ & $1735 \pm 62$ & $1059 \pm 47$ & $818 \pm 31$ \\
$\mathrm{CPE}\left(10^{-6} \cdot \mathrm{F} \cdot \mathrm{s}^{\mathrm{n}-1}\right)$ & $165 \pm 15$ & $262 \pm 17$ & $347 \pm 20$ \\
$\mathrm{n}$ & $0.84 \pm 0.6$ & $0.82 \pm 0.5$ & $0.85 \pm 0.7$ \\
\hline
\end{tabular}

The different corrosion resistance between base material (BM) and weld metal (WM) is documented by all assessed electrochemical values: $\mathrm{E}_{\text {Corr }}, \mathrm{i}_{\text {Corr }}, \mathrm{v}_{\text {Corr }}$ and $\mathrm{R}_{\mathrm{P}}$. Weld metal has lower corrosion resistance than base material in all cases. The highest corrosion resistance of BM and WM is reached in $0.01 \mathrm{M} \mathrm{NaCl}$ solution, this means the highest thermodynamic $\left(\mathrm{E}_{\text {Corr }}\right)$ and kinetic $\left(\mathrm{i}_{\text {Corr }}, \mathrm{v}_{\text {Corr }}\right)$ stability is observed in this $(0.01 \mathrm{M}$ $\mathrm{NaCl}$ ) solution. This fact was supported by the value of $R_{p}$, because here is the lowest concentration of chlorides $=$ the lowest aggresivity of environment. Oppositely, the lowest corrosion resistance from both thermodynamic and kinetic point of view was reached in the environment of highest chloride concentration on both tested surfaces.

Corrosion resistance of weld metal (kinetic point of view) in $1 \mathrm{M}$ sodium chloride solution is about $22 \%$ lower than in $0.1 \mathrm{M} \mathrm{NaCl}$ solution and about $64 \%$ lower than in $0.01 \mathrm{M} \mathrm{NaCl}$ solution. Similar ratios of change in corrosion resistance were reached on base material in tested environments.

\section{Conclusions}

Based on the results from potentiodynamic tests and EIS measurements, which were performed in solutions: $0.01 \mathrm{M}$ $\mathrm{NaCl} ; 0.1 \mathrm{M} \mathrm{NaCl}$ and $1 \mathrm{M} \mathrm{NaCl}$ to determine the $\mathrm{E}_{\text {Corr }}, \mathrm{i}_{\text {Corr }}$ and $\mathrm{v}_{\text {Corr }}$ values of S355J2 steel in areas of base material (BM) and weld metal (WM) it is possible to state:

- With increasing concentration (aggressivity) of chlorides in environment, decreases corrosion resistance of base material and weld metal: $0.01 \mathrm{M} \rightarrow 0.1 \mathrm{M}=$ decreases corrosion resistance about $34 \% ; 0.1 \mathrm{M} \rightarrow 1 \mathrm{M}=$ decreases corrosion resistance about $22 \%$.

- The highest corrosion resistance has base material in $0.01 \mathrm{M}$ sodium chloride solution, because in this environment it is the lowest concentration of chlorides and value of $R_{p}\left(1928 \Omega . \mathrm{cm}^{-2}\right)$ is the highest, value of $\mathrm{E}_{\text {Corr }}(-489 \mathrm{mV})$ is the most positive and the values of $\mathrm{i}_{\text {Corr }}\left(6.5 \mu \mathrm{A} . \mathrm{cm}^{-2}\right)$ and $\mathrm{v}_{\text {Corr }}\left(151 \mu \mathrm{m} . \mathrm{y}^{-1}\right)$ are the lowest.

- The lowest corrosion resistance has weld metal in $1 \mathrm{M}$ chloride environment, because the concentration of chlorides in this solution and aggressivity of environment are the highest. This confirms value of $\mathrm{R}_{\mathrm{p}}\left(818 \Omega . \mathrm{cm}^{-2}\right)$, value of $\mathrm{E}_{\text {Corr }}(-668 \mathrm{mV}), \mathrm{i}_{\text {Corr }}\left(12.5 \mu \mathrm{A} \cdot \mathrm{cm}^{-2}\right)$ and $\mathrm{v}_{\text {Corr }}$ $\left(291 \mu \mathrm{m} . \mathrm{y}^{-1}\right)$. This means that weld metal in $1 \mathrm{M} \mathrm{NaCl}$ has the lowest thermodynamic and kinetic stability.

- Difference of corrosion resistance between base material and weld metal is about $14.5 \pm 1 \%$. This difference is preserved in all concentration of tested environments $(0.01 \mathrm{M}, 0.1 \mathrm{M}$ and $1 \mathrm{M} \mathrm{NaCl})$.

\section{Acknowledgement}

The research was supported by the Slovak Research and Development Agency, project No. APVV-14-0096 and by ERDF projects: ITMS 26220220183, ITMS 26220220048 and ITMS 2014+313011D011.

\section{References}

Alipooramirabad, H., Paradowska, A., Ghomashchi, R., Reid, M. (2017). Investigating the effects of welding process on residual stresses, microstructure and mechanical properties in HSLA steel welds. Journal of Manufacturing Processes. 28(1), pp. 70-81.

https://doi.org/10.1016/j.jmapro.2017.04.030

Ding, J., Zhang, L., Lu, M., Wang, J., Wen, Z., Hao, W. (2014). The electrochemical behavior of $316 \mathrm{~L}$ austenitic stainless steel in $\mathrm{Cl}^{-}$containing environment under different $\mathrm{H}_{2} \mathrm{~S}$ partial pressures. Applied Surface Science. 289 , pp. $33-41$.

https://doi.org/10.1016/j.apsusc.2013.10.080

Forouzan, M. R., Mirfalah Nasiri, S. M., Mokhtari, A., Heidari, A., Golestaneh, S. J. (2012). Residual stress prediction in submerged arc welded spiral pipes. Materials \& Design. 33, pp. 384-394. https://doi.org/10.1016/j.matdes.2011.04.016

Frankel, G. S. (2008). Electrochemical Techniques in Corrosion: Status, Limitations, and Needs. Journal of ASTM International. 5(2), pp. 3-40. https://doi.org/10.1520/JAI101241

Garcia, C. I. (2017). Chapter 6 - High strength low alloyed (HSLA) steels In: Automotive Steels Design, Metallurgy, Processing and Applications. (Rana, R. and Singh, S. B. (eds.)), pp. 145-167. Elsevier Ltd. https://doi.org/10.1016/B978-0-08-100638-2.00006-7

Hadzima, B., Mhaede, M., Pastorek, F. (2014). Electrochemical characteristics of calcium-phosphatized AZ31 Magnesium alloy in $0.9 \% \mathrm{NaCl}$ solution. Journal of Materials Science: Materials in Medicine. 25(5), pp. 1227-1237. https://doi.org/10.1007/s10856-014-5161-0

Han, X. G., Zhu, F., Zhu, X. P., Lei, M. K., Xu, J. J. (2013). Electrochemical corrosion behavior of modified MAO film on magnesium alloy AZ31 irradiated by high-intensity pulsed ion beam. Surface and Coatings Technology. 228, pp. 164-170. https://doi.org/10.1016/j.surfcoat.2012.06.053

Kim, W. K., Koh, S. U., Yang, B. Y., Kim, K. Y. (2008). Effect of environmental and metallurgical factors on hydrogen induced cracking of HSLA steels. Corrosion Science. 50(12), pp. 3336-3342. https://doi.org/10.1016/j.corsci.2008.09.030

Li, J., Wu, J., Wang, Z., Zhang, S., Wu, X., Huang, Y., Li, X. (2017). The effect of nanosized $\mathrm{NbC}$ precipitates on electrochemical corrosion behavior of high-strength low-alloy steel in $3.5 \% \mathrm{NaCl}$ solution. International Journal of Hydrogen Energy. 42(34), pp. 22175-22184. https://doi.org/10.1016/j.ijhydene.2017.03.087

Li, K., Wu, Z., Zhu, Y., Liu, C. (2017). Metal transfer in submerged arc welding. Journal of Materials Processing Technology. 244, pp. 314-319. 
https://doi.org/10.1016/j.jmatprotec.2017.02.004

Liu, W., Pan, H., Li, L., Lv, H., Wu, Z., Cao, F., Zhu, J. (2017). Corrosion behavior of the high strength low alloy steel joined by vertical electro-gas welding and submerged arc welding methods. Journal of Manufacturing Processes. 25, pp. 418-425.

https://doi.org/10.1016/j.jmapro.2016.12.011

Mhaede, M., Pastorek, F., Hadzima, B. (2014). Influence of shot peening on corrosion properties of biocompatible magnesium alloy AZ31 coated by dicalcium phosphate dihidrate (DCPD). Materials Science and Engineering: C. 39, pp. 330-335.

https://doi.org/10.1016/j.msec.2014.03.023

Pastorek, F., Borko, K., Fintová, S., Kajánek, D., Hadzima, B. (2016). Effect of Surface Pretreatment on Quality and Electrochemical Properties of Manganese Phosphate on S355J2 HSLA Steel. Coatings. 6(4), pp. 46-55. https://doi.org/10.3390/coatings6040046

Pu, J., Yu, S., Li, Y. (2017). Role of inclusion in flux aided backing submerged arc welding. Journal of Materials Processing Technology. 240, pp. 145-153. https://doi.org/10.1016/j.jmatprotec.2016.09.016

Ren, D., Xiao, F., Tian, P., Wang, X., Liao, B. (2009). Effect of welding wire composition and welding process on the weld metal toughness of submerged arc welded pipeline steel. International Journal of Minerals, Metallurgy and Materials. 16 (1), pp. 65-70.

https://doi.org/10.1016/S1674-4799(09)60011-X
Sirin, K., Sirin, Y. S., Kaluc, E. (2016). Influence of the interpass temperature on $\mathrm{t}_{8 / 5}$ and the mechanical properties of submerged arc welded pipe. Journal of Materials Processing Technology. 238, pp. 152-159. https://doi.org/10.1016/j.jmatprotec.2016.07.008

Vural, M. (2014). Chapter 6.02 - Welding Processes and Technologies. In: Reference Module in Materials Science and Materials Engineering, Comprehensive Materials Processing. 6: Welding and Bonding Technologies. (Hashmi, S. (ed.)), pp. 3-48. Elsevier Ltd. https://doi.org/10.1016/B978-0-08-096532-1.00603-8

Wei, B., Tokash, J. C., Zhang, F., Kim, Y., Logan, B. E. (2014). Electrochemical analysis of separators used in single-chamber, air-cathode microbial fuel cells. Electrochimica Acta. 89, pp. 45-51.

https://doi.org/10.1016/j.electacta.2012.11.004

Weman, K. (2003). Welding Processes Handbook. Chapter 7 - Submerged arc welding. pp. 68-79. Woodhead Publishing Limited, Sawston, Cambridge, United Kingdom.

https://doi.org/10.1533/9781855738539.68 